\title{
A Bilingualised English Dictionary for Catalan Speakers
}

\author{
Montse Corrius, Departament de Llengües, Ciències Socials i Jurídiques, \\ Universitat de Vic, Vic, Spain (montse.corrius@uvic.cat) \\ and \\ Dídac Pujol, Departament de Traducció i Ciències del Llenguatge, Universitat \\ Pompeu Fabra, Barcelona, Spain (didac.pujol@upf.edu)
}

\begin{abstract}
In view of the benefits of both monolingual and bilingual dictionaries, a new type of dictionary which combines the strong points of a monolingual learner's dictionary with those of a bilingual dictionary was designed and introduced into some Catalan primary and secondary schools: the Easy English Dictionary with a Catalan-English Vocabulary. This article looks in detail at this new kind of dictionary: its philosophy, the way it functions, its advantages over other kinds of dictionaries and the fact that the monolingual part is specifically aimed at Catalan learners of English. Additionally, the article deals with the pedagogical functions of illustrations as well as the adequacy of the dictionary to the lexical needs and requirements of Catalan learners of English in primary and secondary education.
\end{abstract}

Keywords: FOREIGN LANGUAGE LEARNING, BILINGUALISED DICTIONARIES, ILLUSTRATIONS, GLOCALISATION, PEDAGOGICAL DEFINITIONS, CATALAN LEARNERS OF ENGLISH, LEXICOGRAPHY

Opsomming: 'n Tweetalig verklarende Engelse woordeboek vir sprekers van Katalaans. Gesien die voordele van sowel eentalige as tweetalige woordeboeke, is 'n nuwe soort woordeboek wat die sterk punte van 'n eentalige aanleerderswoordeboek met dié van 'n tweetalige woordeboek kombineer, ontwerp en ingevoer in sekere Katalaanse primêre en sekondêre skole: die Easy English Dictionary with a Catalan-English Vocabulary. Hierdie artikel kyk in besonderhede na dié nuwe soort woordeboek: sy filosofie, die manier waarop dit funksioneer, sy voordele bo ander soorte woordeboeke en die feit dat die eentalige deel spesifiek gerig is op Katalaanse aanleerders van Engels. Daarbenewens behandel die artikel die opvoedkundige funksies van illustrasies, asook die leksikale behoeftes en vereistes van Katalaanse aanleerders van Engels in die primêre en sekondêre onderwys.

Sleutelwoorde: VREEMDETAALAANLEER, TWEETALIG VERKLARENDE WOORDEBOEKE, ILLUSTRASIES, GLOKALISERING, OPVOEDKUNDIGE DEFINISIES, KATALAANSE AANLEERDERS VAN ENGELS, LEKSIKOGRAFIE

\section{Introduction}

As has extensively been discussed in the field of foreign language learning, both monolingual and bilingual dictionaries have a series of advantages and disadvantages, which largely condition the choice of one type of dictionary over the other (see Atkins 1985, Fan 2000: 124-125, Laufer and Hadar 1997, 
Nakamoto 1995). On the one hand, monolingual dictionaries immerse learners in the second language, but, especially at elementary levels, they cause frustration among users, who often find the definitions difficult to understand. Bilingual dictionaries, on the other hand, provide immediate access to the learner's native language and are essential when someone does not know how to translate an L1 (native language) word in the L2 (foreign language); therefore, bilingual dictionaries generate confidence in the user, even though they do not immerse learners in the L2 as much as monolingual dictionaries.

In order to overcome the disadvantages of both monolingual and bilingual dictionaries and benefit from the advantages of both kinds of dictionaries, a new concept of dictionary, halfway between monolingual and bilingual dictionaries, was devised: the Easy English Dictionary with a Catalan-English Vocabulary (EED). This new type of dictionary integrates and interrelates a main L2 dictionary (a monolingual English one) and two bilingual dictionaries (an English-Catalan and a Catalan-English one).

\section{The monolingual English dictionary}

The monolingual part of the EED has 4500 entries and 6000 subentries. Its definitions are meant to be simple and are supported by 1000 illustrations. At the end of the book, there is also a grammar appendix presenting explanations of the most useful English grammar points and a selection of maps helping users learn the names of the different countries in the world and their corresponding capitals.

The main characteristics of the monolingual English dictionary which make it innovative and easily understood by a Catalan learner of English are: (a) its glocal approach; (b) its clear and pedagogical definitions; and (c) the pedagogical function of its illustrations.

\subsection{Glocal approach}

Most monolingual learners' dictionaries are aimed at a global market: the same edition is sold in such different countries as Norway, Russia, Spain, Mexico, South Africa and China. This implies that these dictionaries cannot take local linguistic and cultural particularities into account; consequently, they transmit cultural information but encourage cultural homogeneity. Let us take, for example, the definition of 'breakfast' provided by the Macmillan English Dictionary for Advanced Learners:

breakfast noun the first meal you have in the morning: What did you have for breakfast this morning? * I'm never hungry enough for a full breakfast. a. a meal consisting of the things people often have for breakfast, for example eggs or BACON: Try our all-day breakfast - only £3.50! [...]

The first subentry states that people often have eggs and bacon for breakfast. 
The definition provides useful cultural information, but what should be presented as a local specificity (the definition is clearly British-oriented) is in fact presented as a global characteristic (people in general, and not British people, are said often to have eggs and bacon for breakfast).

The EED, on the other hand, is conceived with a glocal (global + local) approach in mind. 'Glocalization' is a portmanteau word that combines the forms and meanings of 'globalization' and 'localization', and it may be defined as the interaction between the local and the global. Let us consider the example of 'breakfast' as defined in the EED:

\section{breakfast $n$}

the meal that you eat in the morning: Some English people have bacon and eggs for breakfast.

The EED provides a general definition of 'breakfast' and then, in the example, points towards a culturally specific element, namely the fact that some British people have bacon and eggs for breakfast. Therefore, the example draws attention to a cultural specificity while avoiding cultural homogeneity.

Apart from this, the monolingual part of the EED tends to promote the understanding of definitions and examples through references to Catalan cultural specificities. The example under the entry 'far', for instance, reads: "Miami is very far from Barcelona; Sabadell is very near Terrassa." Indeed, well-known Catalan cities like Sabadell and Terrassa become meaningful examples to the target reader.

Another entry which is also representative of the glocal approach adopted in this dictionary is 'tongue twister':

\section{tongue twister $n$}

a group of words difficult to pronounce when you say them quickly: 'Setze jutges d'un jutjat mengen fetge d'un penjat' is a Catalan tongue twister; 'She sells sea shells on the seashore' is an English tongue twister.

As expected from a good monolingual learner's dictionary, the EED provides users with an example of 'tongue twister': "She sells sea shells on the seashore." But, unlike most dictionaries aimed at an exclusively global market, the EED resorts to the learner's cultural background ("Setze jutges d'un jutjat mengen fetge d'un penjat") as an effective means of conveying the meaning of 'tongue twister'. The EED is in fact conceived to mediate between the English and the Catalan languages and cultures.

\subsection{Clear and pedagogical definitions}

Except for references to local culture, another aspect which contributes to making the dictionary easier for Catalan speakers is the clear and pedagogical definitions contained in its entries. The conception of the EED, its target users and the trials made in a number of Catalan schools suggested that in the monolingual entries simplicity was to be preferred to lexicographic precision. 
A first step towards clear and pedagogical definitions is the use of a restricted vocabulary. The words used in the definitions and examples are basic words that appear defined in the dictionary and that have been chosen, whenever possible and without renouncing naturalness, for their similarity to Catalan words. Below are a couple of examples illustrating this:

\section{cheetah $n$}

an animal that is similar to a leopard: Cheetahs live in Africa and are the fastest animals in the world.

\section{fortune-teller $n$}

a person who predicts the future by looking at cards, at the lines on your hands, etc.

In the definition of 'cheetah', there are some keywords that, because of their similarity to Catalan, help a Catalan speaker to understand the English text. These are: 'animal', 'similar' and 'leopard'. The Catalan equivalents are animal, similar and leopard respectively. In the case of 'fortune-teller', the words similar to Catalan are: 'person', 'predicts' and 'future'. The Catalan equivalents are persona, prediu and futur respectively.

Apart from this, simple syntax is used to facilitate Catalan users understand the meaning of each entry. Thus, complex structures learnt at an intermediate level, such as conditional phrases, passive constructions and relative clauses have been avoided whenever possible.

Furthermore, in order to help learners understand the English text, in most instances there is an example next to the definition or even an illustration with a clear pedagogical purpose. The examples can be found just after the definition or at the foot of the illustration which, as will be seen in the following section, is aimed at clarifying the meaning and usage of the word. In a few instances, just when the definitions seem too complicated, these have been omitted and only an example - with or without an illustration - has been used:

plus prep

Two plus two equals four $(2+2=4)$.

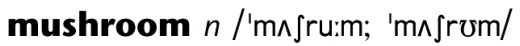
We went to pick mushrooms last Sunday. $667 / 5979$

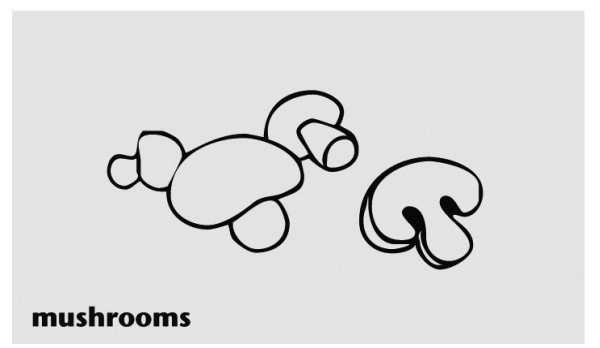

Figure 1: 'mushroom' 
Careful attention has also been paid to the phraseology associated with each word: common lexical combinations, idioms, prepositions, phrasal verbs, etc. Phraseology may be said to be an essential element for the learning of a foreign language, since it shows the most common contexts in which words appear: users, for example, will find the form 'it's raining' under the entry 'rain' because it is a common expression used with 'rain'. A Catalan speaker could make the mistake of saying 'rains' instead of 'it's raining' since in Catalan the subject is not used, so the dictionary helps learners use the right form. A Catalan learner of English should also know that the English say 'to rob a bank' instead of 'to steal a bank', and that they say 'at Christmas' instead of 'in Christmas', so the dictionary reflects this phraseology. When Catalan users look up a word they already know in the EED, they will find additional information: for example, under the entry 'ambulance', which they most probably know because it is very similar to the Catalan form ambulància, they will learn that ambulance is used with the verb 'to call' and not with a verb such as 'to warn', as they would say in Catalan. Something similar may happen with the entry 'Internet', the form of which is exactly the same in Catalan. If they look up this word in the EED, they will find additional information they probably do not know. For example, they will find the lexical combinations 'Internet address', 'Internet user', 'to access the Internet', 'to search for something on the Internet' and 'to surf the Internet'. In the case of the last collocation, a Catalan speaker, translating from Catalan, may make the mistake of saying 'to sail for Internet'.

As the EED is particularly aimed at primary and secondary education students, it also includes the essential cross-curricular vocabulary used in primary and secondary schools. Thus, one can find words related to:

- Mathematics: 'addition', 'subtraction', 'centimetre', 'ounce', 'triangle', 'circle', etc.

- Natural sciences: 'eclipse', 'hurricane', 'earthquake', 'rib', 'lung', etc.

- Social sciences: the names of different countries and their capitals, the names of rivers, mountain ranges, etc.

- Technology: materials ('plastic', 'wood', 'cardboard'), tools ('spade', 'shovel', 'rake'), etc.

_ N New technologies: 'e-mail', 'at' ('@'), 'videoconference', 'cellphone', 'DVD player', etc.

- Language and literature: 'punctuation mark', 'poem', 'play', 'writer', etc.

- Music: 'jazz', 'note', the names of different musical instruments, etc.

- Arts and crafts: 'drawing', 'brush', 'cut-out', 'cardboard', etc.

- Sports: the names of different sports and related expressions ('to score a goal', 'to bounce a ball', etc.).

— Leisure: 'jigsaw puzzle', 'to play marbles', 'disco', etc. 
The above words have not only been defined, as would be expected from any dictionary; in some cases, they also provide encyclopedic (geographical, cultural, social, etc.) information. The examples in the entries below illustrate this point:

ocean $n$

a big sea: There are five oceans in the world: the Atlantic Ocean, the Pacific Ocean, the Indian Ocean, the Arctic Ocean and the Antarctic Ocean.

war $n$

a fight between two or more countries: World War II started in 1939 and finished in 1945.

\subsection{Pedagogical uses of illustrations}

The illustrations in the EED are in no way meant to be fillers: they have a clear pedagogical purpose. They may have one (or several) of the following functions, assisting in: (i) understanding definitions and focusing on common lexical combinations; (ii) expanding vocabulary; (iii) distinguishing between related words; (iv) grouping together related words; and (v) comprehending onomatopoeias.

\subsubsection{Understanding definitions and focusing on common lexical combina- tions}

The most basic function of illustrations is to help users understand the words defined (see Figure 2).

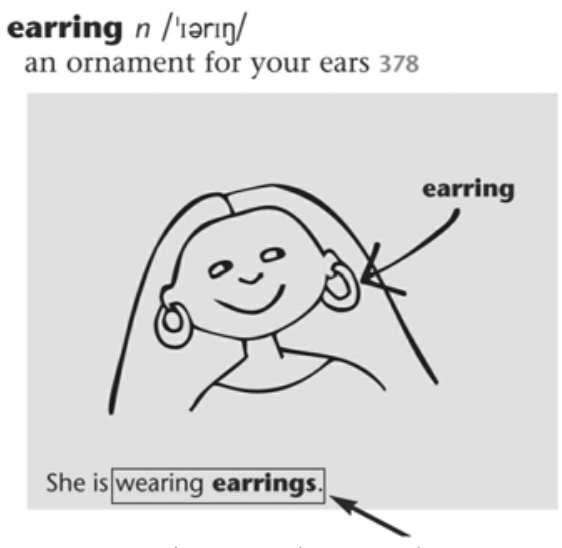

Figure 2: 'earring'

Although the definition in Figure 2 includes a basic word like 'ears' and a word identical in form to Catalan ('ornament'), which may facilitate the understanding of 'earring', the illustration reinforces comprehension and is a useful tool to 
learn the lexical combination 'to wear earrings'. Lexical combinations are key aspects in language learning, for they reflect the way a given word relates to others. Learning lexical combinations, therefore, is an essential step for the learner to produce natural-sounding, idiomatic language in the target language.

\subsubsection{Expanding vocabulary}

Illustrations are also used to expand vocabulary, whether it be by contrast (Figure 3), by segmentation (Figure 4 ) or by contiguity (Figure 5).

smile /smail/

$1 \checkmark$ when we are happy, we smile 5307

$2 n$ an expression of happiness: Theresa is

very nice. She always has a smile on her face. 5307

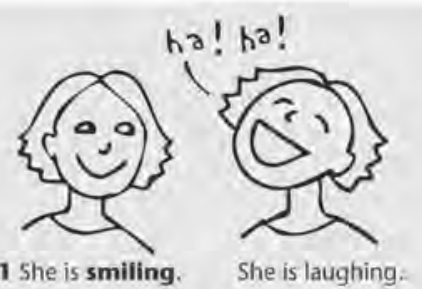

Figure 3: 'smile'

\section{elephant $n$ /'elifant/}

a very large animal with big ears and a

long trunk: Elephants come from India and

Africa, 1873

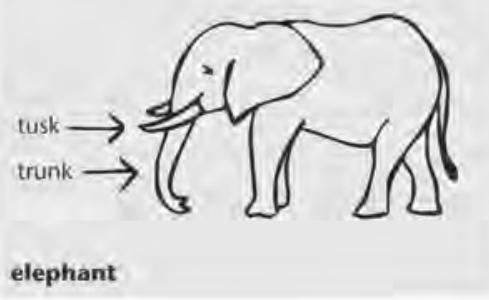

Figure 4: 'elephant'

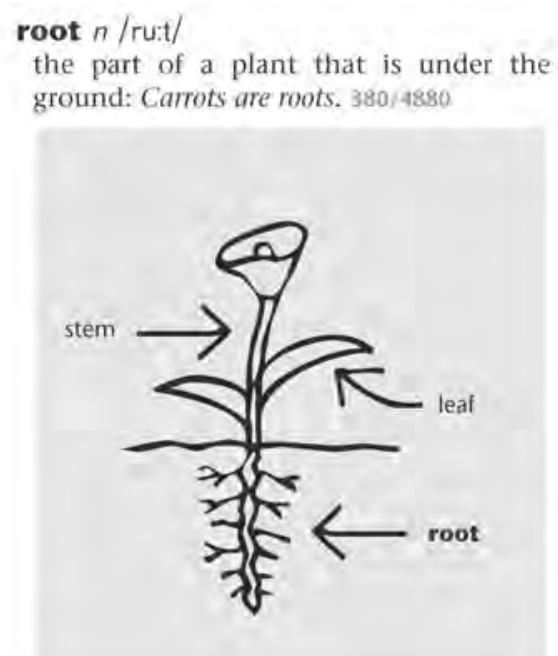

Figure 5: 'root' 


\subsubsection{Distinguishing between related words}

Some illustrations help the learner realise that what in Catalan is expressed by a single word, in English may have several equivalents. The word escala, for example, has three different equivalents in English, namely 'stairs', 'escalator', and 'ladder' (see Figure 6).

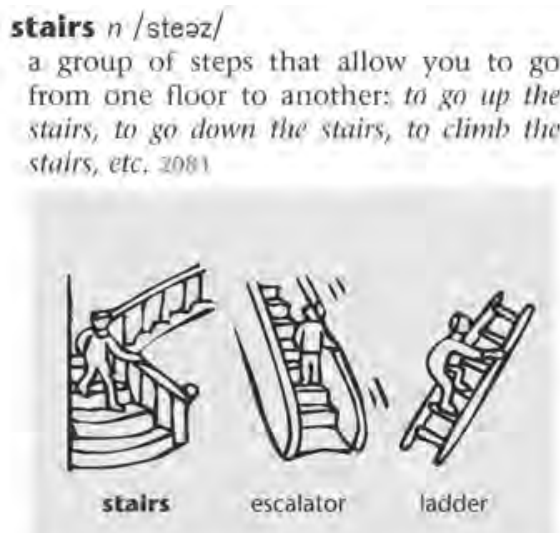

Figure 6: 'stairs'

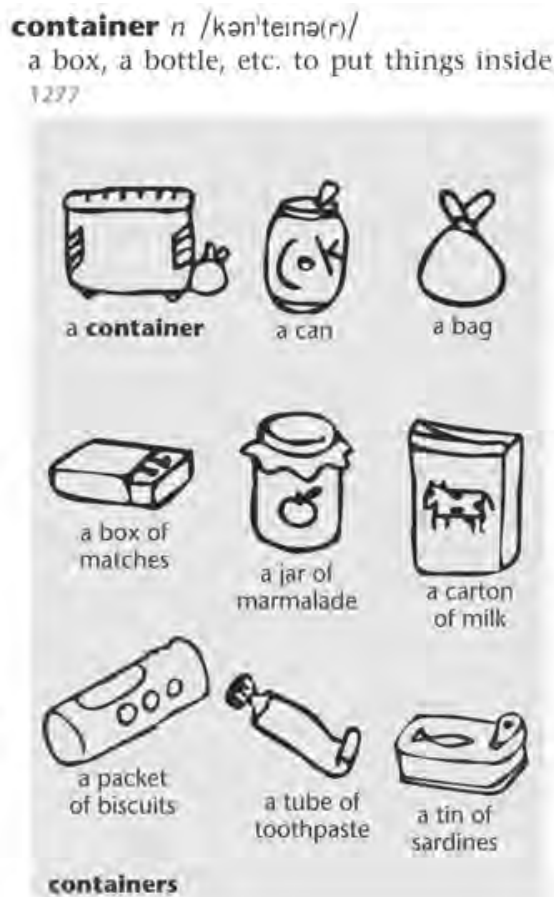

Figure 7: 'container' 


\subsubsection{Grouping together related words}

Some pictures group semantically related words together. Thus, the entry 'insect' includes an illustration with the most common types of insects (a mosquito, an ant, a butterfly and a fly). Likewise, the entry 'container' (Figure 7) illustrates different kinds of containers.

\subsubsection{Comprehending onomatopoeias}

Figure 8 includes the onomatopoeia for a cock's crow.

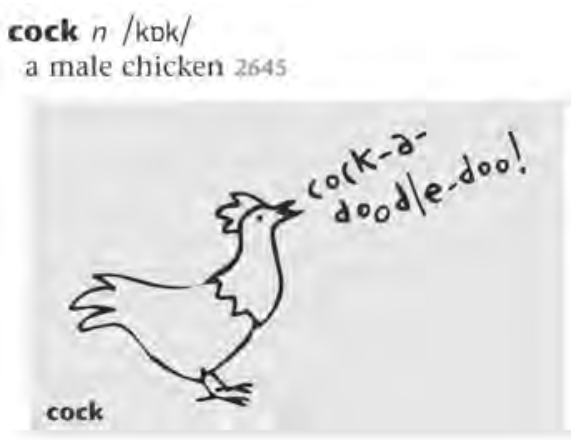

Figure 8: 'cock'

The EED illustrates the most common onomatopoeias, for example 'woof! woof!' (under the entry 'dog'), 'baa! baa!' (under the entry 'sheep'), 'achoo!' (under the entry 'sneeze'), or 'ha! ha!' (under the entry 'laugh').

\section{Integration and interrelation of a monolingual and two bilingual dic- tionaries}

The EED is a 'bilingualised' dictionary. This means that translations into the learner's own language also appear in the dictionary. There are two kinds of bilingualised dictionaries: immediate and deferred (see Pujol, Corrius and Masnou 2006). In immediate bilingualised dictionaries the translation comes immediately after the monolingual part, that is to say next to the definition of the word. The following is an example from an immediate bilingualised dictionary, the Password diccionario didáctico/Password English Dictionary for Speakers of Spanish:

timetable n. list which shows the times of trains/aircraft/classes in school/ appointments: have you the latest train timetable?; there are two English lessons on the timetable today; we have to keep to a strict timetable of appointments.

$\square$ horario 
As can be observed, the advantage of immediate bilingualised dictionaries is that users find the translation directly after the definition (in this case, horario is the translation of 'timetable'). An objection, though, can be made to this type of dictionary: 'Do the users really read the L2 text?' (Nakamoto 1995: section 5). In other words: do users go straight to the translation, dismissing the L2 part? Two studies point in this direction. The first study is by Laufer and Kimmel (1997: 367): they find that in immediate bilingualised dictionaries the highest percentage $(31 \%)$ of (immediate) bilingualised dictionary users read only the L1 text, while $27 \%$ of users read only the monolingual L2 part. The second study is by Thumb (2004: 91): she discovers that 39\% of users read only the L1 translation, thus skipping the monolingual L2 part.

In order to overcome the practice that users skip the monolingual L2 part in immediate bilingualised dictionaries, the deferred bilingualised dictionary was conceived. In this type of dictionary, translations do not immediately follow the monolingual L2 part; rather, they are deferred to the second part of the dictionary. Figure 9 illustrates this.

Monolingual English dictionary

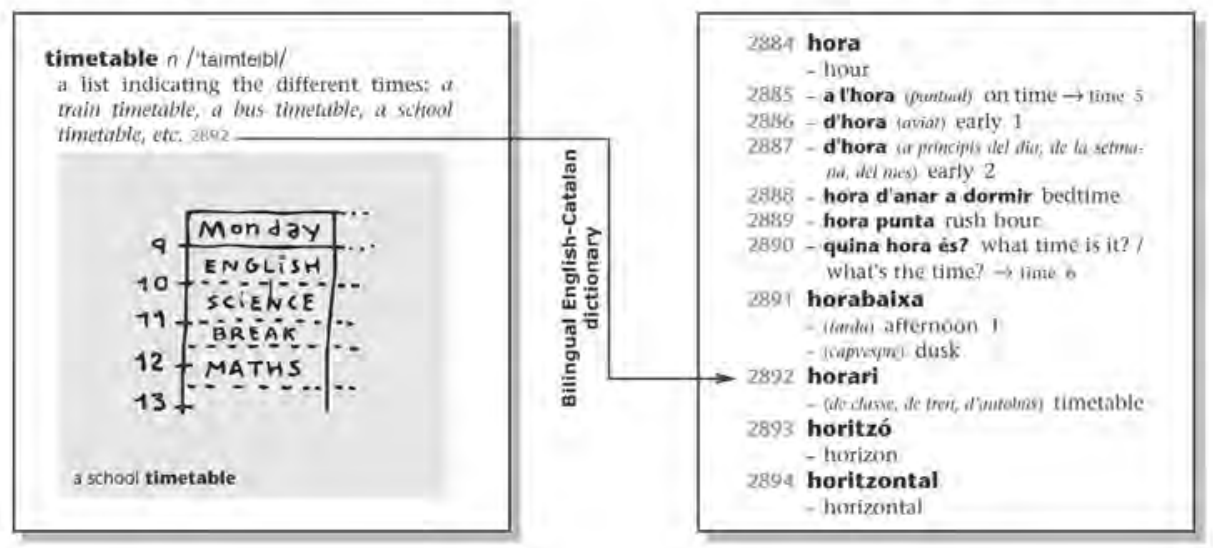

Figure 9: Macrostructure of the EED (1)

In Figure 9, it will be noted that in the monolingual English dictionary at the very end of each entry (or subentry) there is a small number (or a series of numbers) which directs the user towards the Catalan translation of the English word. Thus, in the case where users do not understand the meaning of 'timetable', they can resort to the number 2892 in order to find out, in the second part of the dictionary, its corresponding Catalan translation: horari. The interrelation, by means of numbers, between the monolingual English part of the dictionary and the Catalan translations makes up the bilingual English-Catalan dictionary, which in turn acts as a bilingual Catalan-English dictionary. 
On occasion, it can be seen that a Catalan lexical combination is translated as an English lexical combination (see Figure 10).

Bilingual Catalan-English dictionary Monolingual English dictionary

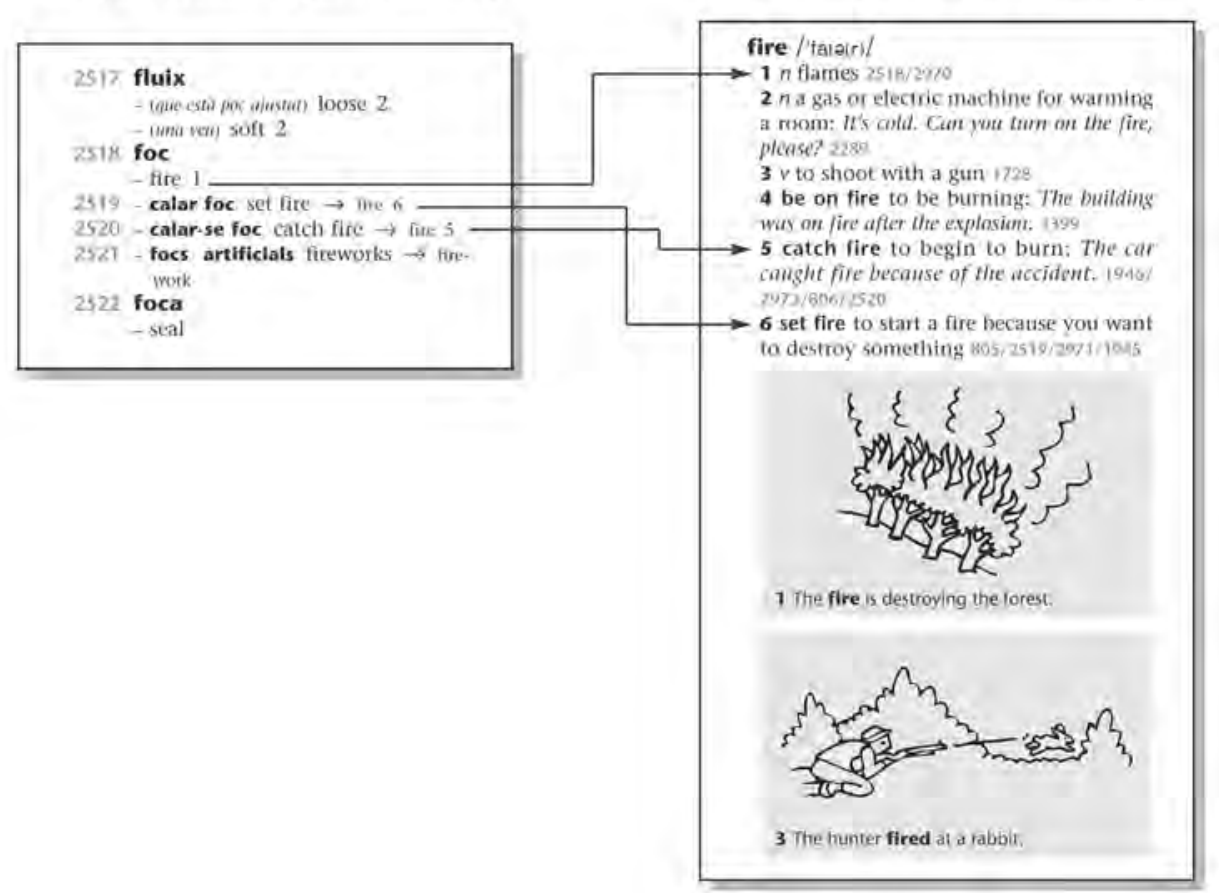

Figure 10: Macrostructure of the EED (2)

In Figure 10, the lexical combination calar-se foc is translated as 'catch fire', and the keyword after the arrow ('fire 5') refers users, in case they need further information, especially for oral or written production, to the monolingual English part. The same applies to calar foc 'set fire': the keyword refers users to 'fire 6'. Apart from the keywords, another feature that needs pointing out is the inclusion of numbers after certain Catalan $\rightarrow$ English translations. Thus, the number 1 after 'fire' indicates that this particular meaning of 'fire' corresponds to the first subentry in the monolingual English dictionary.

The EED thus integrates a monolingual L2 dictionary and two bilingual dictionaries: a bilingual L2 $\rightarrow$ L1 (English-Catalan) dictionary and a bilingual $\mathrm{L} 1 \rightarrow \mathrm{L} 2$ (Catalan-English) dictionary. These are not separate units simply brought together in one book, that is: the three dictionaries are not juxtaposed, but are interrelated in such a way that there is circularity. Owing to circularity, the monolingual dictionary (for example 'raise' in Figure 11) takes users to the bilingual (English-Catalan) section (apujar), which in turn takes them to the bilingual (Catalan-English) dictionary (apujar $\rightarrow$ 'turn up'; apujar $\rightarrow$ 'increase'), 
which further takes them to the monolingual (English) part ('turn 7' and 'increase 1 '):

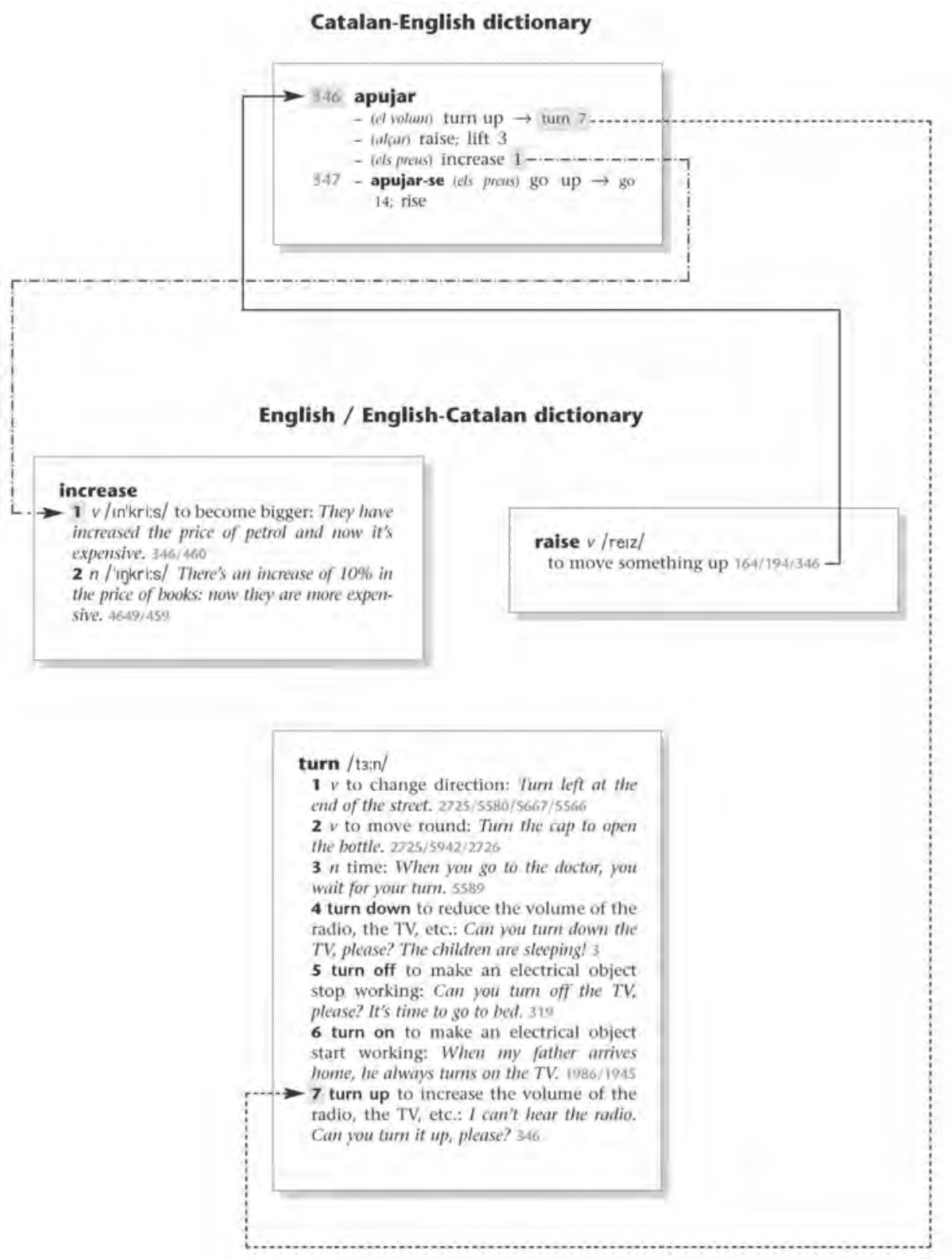

Figure 11: Macrostructure of the EED (3) 


\section{Conclusion}

The EED is a new concept of dictionary that integrates and interrelates three different types of dictionaries: a monolingual L2 one, a bilingual L2 $\rightarrow \mathrm{L} 1$ one, and a bilingual L1 $\rightarrow \mathrm{L} 2$ one. The dictionary, aimed at Catalan learners of English as a foreign language, consists of three different parts, two of them physically differentiated (the monolingual English dictionary and the bilingual Catalan-English dictionary) and one (the bilingual English-Catalan dictionary) establishing a relation between the other two parts. The main purpose of this type of dictionary is to encourage students to use monolingual dictionaries as much as possible, without denying them the possibility of access to translations. In doing so, learners can benefit from the strengths of both monolingual and bilingual dictionaries.

The monolingual English part takes into account the special needs and requirements of learners of English in primary and secondary education, which is mainly reflected in the clear and pedagogical definitions and the pedagogical uses of illustrations. The monolingual part has also been conceived with a glocal approach, which helps Catalan speakers understand the definitions in the foreign language and provides both English and Catalan specific cultural information. Additionally, the monolingual English dictionary directs the user towards the bilingual English-Catalan part, which contains the translations. To conclude: the integration and interrelation of three different types of dictionary and the particular conception of both the monolingual and the bilingual parts make the EED a helpful tool for learning English as a foreign language and a model that can be adapted to other languages, for example, English and Afrikaans, or one or other of the African languages.

\section{References}

Atkins, Beryl T. 1985. Monolingual and Bilingual Learners' Dictionaries: A Comparison. Ilson, Robert (Ed.). 1985. Dictionaries, Lexicography and Language Learning: 15-24. Oxford: Pergamon Press/The British Council.

Easy English Dictionary with a Catalan-English Vocabulary. 2004. Vic: Eumo Editorial.

Fan, May Y. 2000. The Dictionary Look-Up Behavior of Hong Kong Students: A Large-Scale Survey. Educational Journal 28(1): 123-138.

Laufer, Batia and Linor Hadar. 1997. Assessing the Effectiveness of Monolingual, Bilingual, and 'Bilingualised' Dictionaries in the Comprehension and Production of New Words. The Modern Language Journal 81(2): 189-196.

Laufer, Batia and Michal Kimmel. 1997. Bilingualised Dictionaries: How Learners Really Use Them. System 25(3): 361-369.

Macmillan English Dictionary for Advanced Learners. 2002. (Edited by M. Rundell and G. Fox.) London: Macmillan.

Nakamoto, Kyohei. 1995. Monolingual or Bilingual, That is Not the Question: The 'Bilingualised' Dictionary. Kernerman Dictionary News 2. http://kdictionaries.com/newsletter/kdn2-2.html. 
Password diccionario didáctico/Password English Dictionary for Speakers of Spanish. 2002. Sixth Edition. Madrid: SM.

Pujol, Dídac, Corrius Montse and Joan Masnou. 2006. Print Deferred Bilingualised Dictionaries and their Implications for Effective Language Learning: A New Approach to Pedagogical Lexicography. International Journal of Lexicography 19(2): 197-215.

Thumb, Jenny. 2004. Dictionary Look-up Strategies and the Bilingualised Learner's Dictionary: A Thinkaloud Study. Lexicographica. Series Maior 117. Tübingen: Max Niemeyer Verlag. 